\title{
KINEZITERAPIJOS STUDENTŲ LIEMENS IR KOJŲ RAUMENŲ FUNKCINIO PAJÉGUMO BEI PUSIAUSVYROS SĄSAJOS
}

\author{
Ieva Eglẻ Jamontaite் ${ }^{1,2}$, Gabrielė Molevičiūtė ${ }^{1}$, Inga Muntianaitė ${ }^{1}$, Ligita Aučynienè1, \\ Alma Cirtautas ${ }^{1,2}$, Ramunė Žilinskiene் ${ }^{1}$ \\ ${ }^{1}$ Vilniaus universiteto Medicinos fakulteto Sveikatos moksly institutas, \\ ${ }^{2}$ Vilniaus universiteto ligoninès Santaros kliniku Reabilitacijos, fizinès ir sporto medicinos centras
}

Raktažodžiai: liemens raumenų jèga, liemens raumenų ištvermè, kojų raumenų jèga, kojų raumenų ištvermè, funkcinis pajègumas, pusiausvyra, kineziterapijos studentai.

\begin{abstract}
Santrauka
Tyrimo tikslas - įvertinti kineziterapijos studentų liemens ir kojų raumenų funkcinį pajègumą bei pusiausvyrą ir nustatyti šių rodiklių tarpusavio sąsajas. Tyrime dalyvavo 30 kineziterapijos studijų programos ketvirto kurso studentų ( 25 moterys ir 5 vyrai), amžiaus vidurkis $22,4 \pm 1,2$ metai. Tiriamujų liemens ir kojų raumenų jëga testuota dr. Wolff „Back check“ diagnostikos aparatu, kojų raumenų ištvermè - tūptistotis testu, statinè pusiausvyra - „Stork“ pusiausvyros testu, dinaminè pusiausvyra - modifikuotu „Žvaigždès“ nuokrypio testu.

Rezultatai. Kineziterapijos studentų liemenị lenkiančių ir tiesiančių raumenų jègos santykis daugiausia buvo ịvertintas labai blogai, šoninių raumenų jègos santykis - labai gerai. Studentų šlaunị tiesiančių raumenų jëgos santykis buvo ịvertintas labai gerai, o šlauni pritraukiančių raumenų jègos santykis buvo pasiskirstęs beveik vienodai visose vertinimo grupėse (labai blogai, blogai, patenkinamai, gerai, labai gerai). Šlauni atitraukiančių raumenų jègos santykis tarp kairès ir dešinès kojų ịvertintas labai blogai. Daugumos studentų kojų raumenų ištvermè įvertinta kaip pakankama. İvertinus kineziterapijos studentu pusiausvyrą, pastebėta, jog statinè pusiausvyra yra gan prasta, o dinaminé pusiausvyra ịvertinta gerai. Nustatyta, jog nugaros raumenų jèga ir ištvermè statistiškai reikšmingai $(p<0,05)$ koreliuoja su dinamine pusiausvyra, liemens raumenų jèga reikšmingai koreliuoja su kojų raumenų jèga, kojų raumenų jèga iš dalies koreliuoja su dinamine pusiausvyra, o koju raumenų ištvermé - su statine pusiausvyra.
\end{abstract}

Išvados. Liemens funkcinio pajègumo tyrimu nustatyta, kad tiriamujų pilvo ir nugaros raumenų jègos santykis ir šoninių liemens raumenų jẻgos santykis yra patenkinamas. Vertinant kineziterapijos studentuc kojų raumenų funkcini pajègumą, nustatyta, jog tiriamujų šlaunị tiesiančių, atitraukiančių ir pritraukiančių raumenų jègos santykis tarp kairès ir dešinès kojos yra patenkinamas. Studentų statiné pusiausvyra patenkinama. Analizuojant liemens, kojų raumenų pajëgumo ir pusiausvyros tarpusavio ryšius, nustatyta, kad kuo didesnè izometrinè liemens raumenų jèga, tuo didesné kojų raumenų jèga. Didesnè izometrinė nugaros raumenų jèga lemia geresnę dinaminę pusiausvyrą. Kuo didesnè kojų raumenų jèga, tuo geresnè dinaminè pusiausvyra ir geresnè kojų raumenų ištvermè, lemianti geresnę statinę pusiausvyrą.

\section{İvadas}

Sumažejjusi liemens raumenu jèga ir ištvermè veikia viso kūno funkcinius judesius [1]. Viena iš pagrindinių liemens raumenų funkcijų yra išlaikyti liemeni vertikalioje padètyje ir stabilizuoti stuburą. Tai reikalauja optimalios liemens raumenų ištvermès ir jègos, kuri reikalinga ne tik gerai liemens funkcijai, bet ir apatinių galūnių judesių stabilumui ir pusiausvyrai [2]. Sumažèjęs šių raumenų aktyvumas, įsijungimas ne vienu metu, gali nulemti padidejusią liemens, apatinių galūnių traumų tikimybę ar net pusiausvyros pablogèjimą [3]. A. Aggarwal su kolegomis jau seniai pastebejjo, jog sportininkai gerokai dažniau patiria apatinès kūno dalies traumas, kai liemens raumenų jëga yra nepakankama [4].

Gera pusiausvyra yra vienodai svarbi ir kasdieneje, ir sportinėje veikloje. Pusiausvyros kontrolès blogejjimas daro nemenką įtaką asmens savarankiškumui ir gyvenimo kokybei. Nors pedos raumenys yra vieni iš pagrindinių raumenų, dalyvaujančiu pusiausvyros išlaikyme, šlaunies raumenys taip pat atlieka svarbų vaidmenį, kontroliuojant kūno svyra- 
vimus [5]. Atliekant pratimus ant nestabilių plokštumų, tam tikrų liemens raumenų aktyvumas padidejja, tad galime teigti, jog pusiausvyros išlaikymas priklauso ir nuo liemens, ir nuo kojų raumenų funkcinio pajègumo. Tai įrodo, kad turime žiūrèti ị žmogaus kūną kaip ị visumą ir net menkiausias pakitimas liemens ar klubo srityje gali sukelti pokyčius ir distalinèje apatiniu galūnių dalyje, ir pusiausvyros valdyme. Be to, laiku pastebėtas ir pradètas gerinti liemens ir kojų raumenų funkcinio pajègumo sumažèjimas padès sumažinti traumų ir nugaros skausmo tikimybę vyresniame amžiuje. Ypač tai aktualu kineziterapijos studentams ir jauniems specialistams, kurie dèl neteisingų ergonominių padéčių, dirbdami su pacientais praktikos metu ir pirmaisiais darbo metais, dažnai patiria apatinès nugaros dalies skausmus ar net traumas [6].

Darbo tikslas - ịvertinti kineziterapijos studentų liemens ir kojų raumenų funkcinį pajègumą bei pusiausvyrą ir nustatyti šių rodiklių tarpusavio sąsajas.

\section{Tyrimo objektas ir metodas}

Tyrime dalyvavo 30 kineziterapijos ketvirto kurso studentų: 25 moterys, 5 vyrai. Tiriamujų amžiaus vidurkis 22,4 $\pm 1,2$ metai. Tyrimo metu buvo skaičiuojami antropometriniai duomenys: ūgis (vidurkis $169,9 \pm 7,97 \mathrm{~cm}$ ) ir svoris (vidurkis $62,6 \pm 10,3 \mathrm{~kg})$.

Tiriamieji buvo atrinkti pagal šiuos įtraukimo kriterijus: ketvirto kurso kineziterapijos studentas; neturi kaulu raumenų sistemos ligų ar traumų, galinčių paveikti tyrimo rezultatus.

Tiriamieji buvo supažindinami su tyrimo eiga, trukme bei rezultatų panaudojimo tikslu. Taip pat informuojami apie teisę atsisakyti dalyvauti tyrime. Buvo atliekamas vienmomentinis tyrimas.

Izometrinès liemens ir kojų raumenų jëgos vertinimas atliktas dr.Wolff „Back-check“ testu. Back-check - tai elektroninis raumenu jègos vertinimo prietaisas, matuojantis nugaros, viršutinių ir apatinių galūnių raumenų izometrinę jègą (svorị kg), naudojant du vertinimo jutiklius, esant pa-

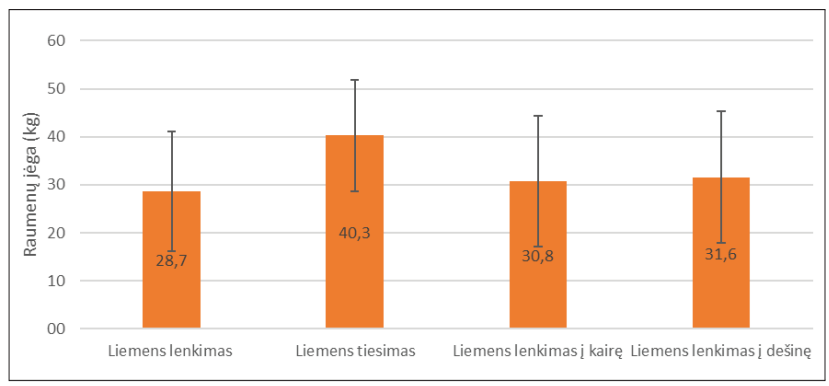

1 pav. Kineziterapijos studentų vidutinė liemens izometrinė raumenų jèga $(\mathrm{kg})$ stoviam pasipriešinimui, uždaroje kinetinèje grandinèje. Tyrimo metu buvo vertinama pacientų liemenį lenkiančių, tiesiančių, ị šoną lenkiančių, šlaunị tiesiančių, pritraukiančių ir atitraukiančių raumenų izometrinè jèga [7].

Kojų raumenų statinès ištvermès vertinimas atliktas taikant tūpti-stotis testą. Tiriamojo prašoma atsistoti tiesiai, pėdos pečių plotyje. Tyrimo metu reikia kuo daugiau kartų atsitūpti-atsistoti per minutę. Tiriamasis tupiasi taip, kad kojos per kelius būtų sulenktos $90^{\circ}$ kampu ir stojasi kuo greičiau [8].

Dinaminès pusiausvyros vertinimas atliktas taikant modifikuotą „Žvaigždès“ nuokrypio pusiausvyros Y-testą (angl. $\mathrm{Y}$ balance test), naudojamą įvertinti dinaminę pusiausvyrą. Gauti rezultatai buvo lyginami su nustatytais procentiniais traumos tikimybės dydžiais. Jei tiriamujų dinaminès pusiausvyros testo rezultatų trijose ašyse (i priekị, i vidų, i išorę) skirtumas tarp dešiniojo ir kairiojo atstumų kiekvienai krypčiai atskirai didesnis nei $4 \mathrm{~cm}$, didèja traumų rizikos tikimybe [9].

Statinès pusiausvyros vertinimas atliktas naudojant „Stork“ pusiausvyros testą (angl. Stork balance stand test). Tyrimo metu vertinama tiriamųjų statinè pusiausvyra, kai reikia išstovèti pasistiebus ant vienos kojos kuo ilgiau. Kiekviena koja testas atliekamas tris kartus ir įskaitomas geriausias rezultatas, sekundemis [10].

\section{Rezultatai ir jų aptarimas}

Buvo ịvertinta visų tiriamujų izometrinè liemens raumenų jèga: pilvo raumenų jègos vidurkis buvo 40,3 $\pm 11,6$ $\mathrm{kg}$, mažiausia reikšmẻ $16 \mathrm{~kg}$, didžiausia $-55 \mathrm{~kg}$, nugaros raumenų jẻgos vidurkis $28,7 \pm 12,5 \mathrm{~kg}$, mažiausia reikšmé 25 $\mathrm{kg}$, didžiausia $-69 \mathrm{~kg}$, kairiojo šono raumenu jègos vidurkis $30,8 \pm 13,6 \mathrm{~kg}$, mažiausia reikšmé $11,5 \mathrm{~kg}$, didžiausia $74,5 \mathrm{~kg}$, dešiniojo šono raumenu jëgos vidurkis $31,6 \pm 13,7$ $\mathrm{kg}$, mažiausia reikšmė $13 \mathrm{~kg}$, didžiausia $-73 \mathrm{~kg}$ (1 pav.). Vidutinis raumenu jègos santykis tarp pilvo ir nugaros raumenų bei tarp dešinès ir kairès pusès liemens raumenų yra patenkinamas.

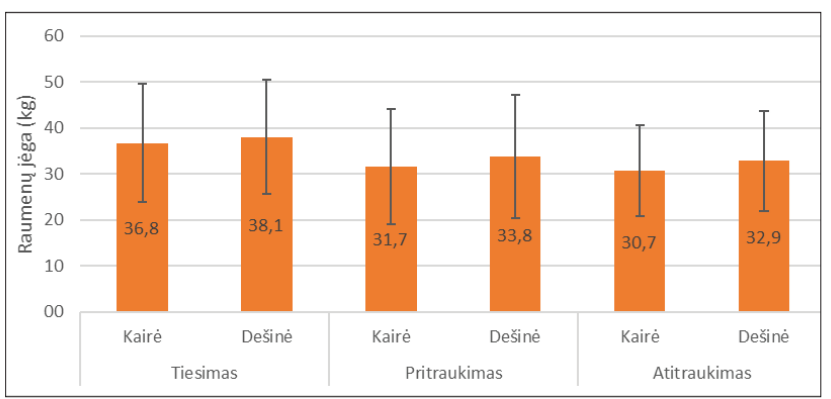

2 pav. Kineziterapijos studentų vidutinė izometrinė kojų raumenų jèga $(\mathrm{kg})$ 

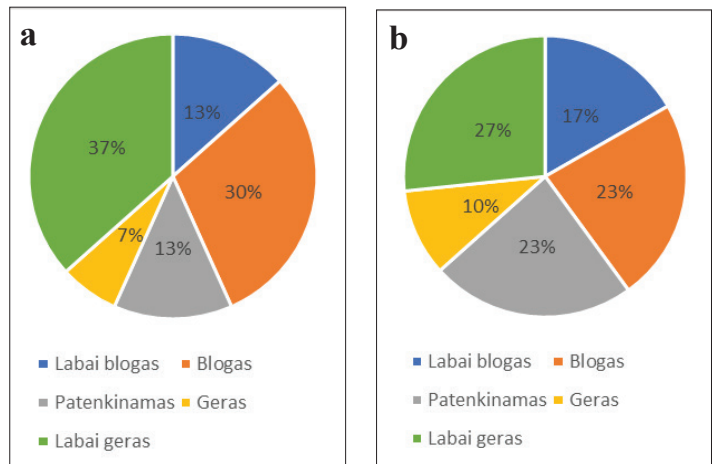

3 pav. Tiriamujų izometrinės tiesiamujų (a) ir pritraukiamujų (b) šlaunies raumenų jẻgos santykio įvertinimas

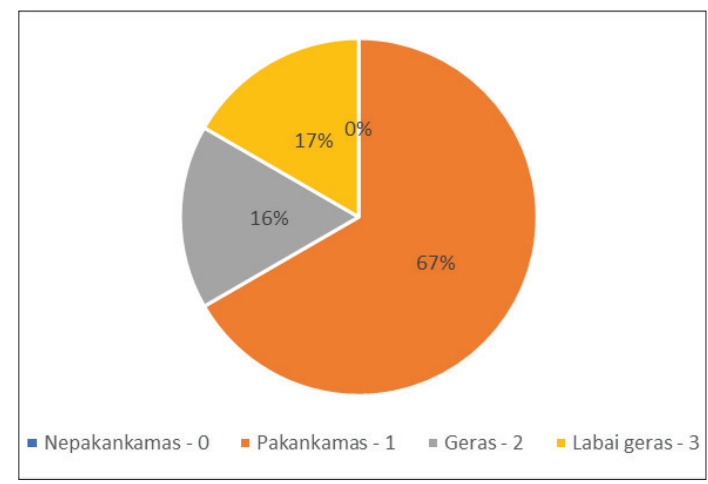

4 pav. Tiriamujų pasiskirstymas pagal kojų raumenų ištvermès rezultatus

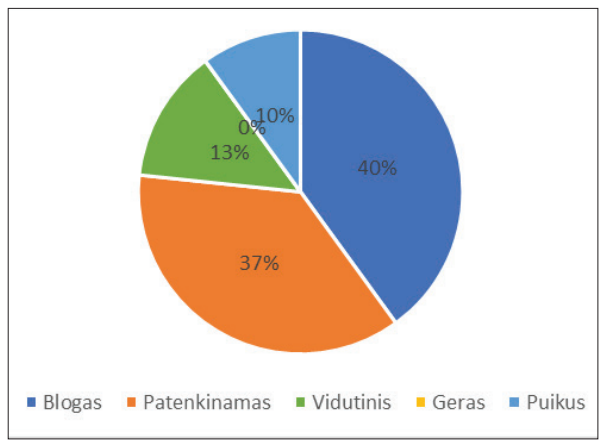

5 pav. Tiriamujų pasiskirstymas pagal statinès pusiausvyros rezultatus

Tyrimo metu buvo vertinama izometrinė kojų šlaunies tiesiamujų, atitraukiamųjų ir pritraukiamujjų raumenų jèga, kurios rezultatai pateikiami 2 paveiksle.

Apskaičiuotas kairès ir dešinės pusių santykis, kuris buvo suskirstytas i penkias kategorijas (labai blogas, blogas, patenkinamas, geras ir idealus). Apskaičiavus izometrinị kojų raumenu jègos santykị, pastebèti geresni rezultatai, nei izometrinès liemens raumenu jẻgos santykio. Iš 30 tiriamuju labai blogai ịvertinti 4, blogai 9, patenkinamai 4, gerai -2 studentai. 11 studentu izometrinès raumenu jègos santykis tarp kairès ir dešinès pusès šlaunies tiesiamuju raumenu buvo labai geras (3 pav., a). Vidutinis izometrinès šlaunies tiesiamųjų raumenų jëgos santykis tarp kairès ir dešinès kojos buvo patenkinamas.

Vertinant izometrinės šlaunies pritraukiamujų raumenų

1 lentelè. Koreliacinis ryšys tarp izometrinès liemens ir kojų raumenų jẻgos bei pusiausvyros

* - Koreliacija statistiškai reikšminga $(p<0,05), r$-koreliacijos koeficientas

\begin{tabular}{|c|c|c|c|c|c|c|c|c|c|c|c|}
\hline \multirow{3}{*}{ Rodikliai } & \multirow{2}{*}{\multicolumn{2}{|c|}{$\begin{array}{c}\text { Dinamine } \\
\text { pusiausvyra }\end{array}$}} & \multirow{2}{*}{\multicolumn{2}{|c|}{$\begin{array}{c}\text { Statinè pu- } \\
\text { siausvyra }\end{array}$}} & \multicolumn{6}{|c|}{ Šlaunies raumenų jèga } & \multirow{3}{*}{$\begin{array}{l}\text { Apatinių } \\
\text { galūnių } \\
\text { ištvermé } \\
\text { r }\end{array}$} \\
\hline & & & & & \multicolumn{2}{|c|}{ tiesiamųjų } & \multicolumn{2}{|c|}{ pritraukiamųjų } & \multicolumn{2}{|c|}{ atitraukiamujų } & \\
\hline & $\begin{array}{c}\text { kairé } \\
\mathrm{r}\end{array}$ & $\begin{array}{c}\text { dešiné } \\
\mathrm{r}\end{array}$ & $\begin{array}{c}\text { kairè } \\
\mathrm{r}\end{array}$ & $\begin{array}{c}\text { dešinè } \\
\mathrm{r}\end{array}$ & $\begin{array}{c}\text { kairè } \\
\mathrm{r}\end{array}$ & $\begin{array}{c}\text { dešinè } \\
r\end{array}$ & $\begin{array}{c}\text { kairè } \\
\mathrm{r}\end{array}$ & $\begin{array}{c}\text { dešinè } \\
\mathrm{r}\end{array}$ & $\begin{array}{c}\text { kairé } \\
\mathrm{r}\end{array}$ & $\begin{array}{c}\text { dešinè } \\
\mathrm{r}\end{array}$ & \\
\hline $\begin{array}{l}\text { Liemens lenkia- } \\
\text { mųjų raumenų } \\
\text { jëga }\end{array}$ & 0,305 & 0,292 & 0,269 & 0,234 & $0,598^{*}$ & $0,634 *$ & $0,679 *$ & $0,75^{*}$ & $0,446 *$ & $0,666^{*}$ & 0,328 \\
\hline $\begin{array}{l}\text { Liemens tiesia- } \\
\text { mųjų raumenų } \\
\text { jèga }\end{array}$ & $0,372 *$ & $0,404 *$ & 0,223 & 0,241 & $0,561 *$ & $0,64 *$ & $0,73 *$ & $0,743 *$ & $0,633 *$ & $0,729 *$ & $\mathbf{0 , 3 7 5 *}$ \\
\hline $\begin{array}{l}\text { Liemens kairès } \\
\text { pusès lenkia- } \\
\text { mųjų raumenų } \\
\text { jëga }\end{array}$ & 0,197 & 0,171 & 0,286 & 0,275 & $0,574 *$ & $0,584 *$ & $0,673 *$ & $0,645^{*}$ & $0,586^{*}$ & $0,66^{*}$ & $0,38 *$ \\
\hline $\begin{array}{l}\text { Liemens dešinès } \\
\text { pusès lenkia- } \\
\text { mųjų raumenų } \\
\text { jëga }\end{array}$ & 0,175 & 0,149 & 0,229 & 0,152 & $0,583 *$ & $0,596 *$ & $0,567 *$ & $0,599 *$ & $0,459 *$ & $0,604^{*}$ & $0,382 *$ \\
\hline
\end{tabular}


jègos santykị tarp dešinės ir kairès galūnès, pastebèti panašūs rezultatai, kaip ir šlaunies tiesiamujų raumenų (3 pav., b). Vertinant šlaunies atitraukiamujų raumenų jẻgos santykị tarp kairès ir dešinès galūnès, 11 tiriamųjų rezultatai ịvertinti labai blogai, 2 blogai, 9 patenkinamai, 5 gerai ir 3 labai gerai. Vidutinis šlauni atitraukiančių raumenų jègos santykis tarp kairès ir dešinès kojos yra patenkinamas.

Panašūs rezultatai buvo gauti D. Mockevičienès ir kolegų tyrime, kuriame tiriamieji taip pat buvo testuoti su diagnostiniu dr. Wolff testavimo centru „Back-check“. Tyrime liemens raumenų jègos santykis įvertintas kaip labai blogas 64,20 proc. tiriamujų, o dauguma rezultatų buvo labai blogi, blogi ir patenkinami [11]. Priešingai nei D. Mockevičienès tyrime, mūsų tyrime dauguma studentų pasižymèjo geru šoninių liemens raumenų santykiu, nors apskaičiavus vidutinị kairiojo ir dešiniojo šono raumenų jẻgos santykị, jis buvo patenkinamas.

İvertinta tiriamųjų apatinių galūnių ištvermè. Per minutę tiriamieji turejjo pritūpti tiek kartų, kiek pajejgia. Apskaičiavus rezultatus, vidutinis pritūpimų skaičius buvo 47,6 6 , 9 pritūpimai per minutę. Mažiausia reikšmė 41 kartas per min., didžiausia 68 kartai per minutę. 20 tiriamujjų raumenų ištvermé ivvertinta kaip pakankama, 5 gera ir 5 labai gera (4 pav.).

Tyrimo metu buvo vertinama dinaminé pusiausvyra. Kineziterapijos studentų vidutiniai dinaminės pusiausvyros kombinuoti rezultatai abiejų kojų buvo didesni nei 94 proc.: dešinès 94,7 proc., kairès 94,6 procentai. Atlikus tyrimą nustatyta, jog kineziterapijos studentų kojų atstumų skirtumai tarp dešinės ir kairės pusių atliekant dinaminès pusiausvyros testą trijose ašyse (i priekị, ị vidų, ị išorę) mažesni, nei 4 centimetrai.

Buvo įvertinta tiriamujų statiné pusiausvyra, stovint ant vienos kojos (5 pav.). „Stork“ testo vidutinis rezultatas buvo

2 lentelė. Kojų raumenų jègos ir pusiausvyros koreliacinis ryšys * - Koreliacija statistiškai reikšminga $(p<0,05), r$-koreliacijos koeficientas

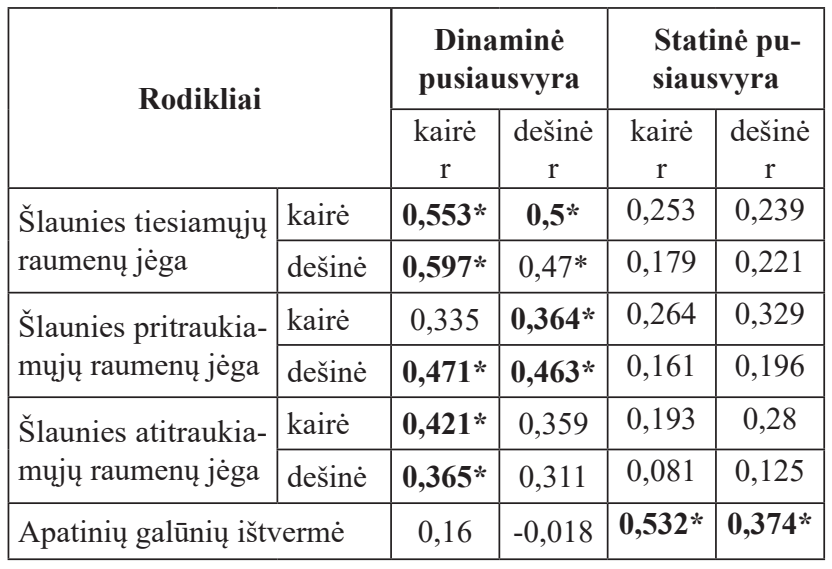

$14,6 \pm 14,9$ sekundės. Tiriamujų rezultatai suskirstyti ị penkias kategorijas (blogas, patenkinamas, vidutinis, geras ir puikus). Nustatyta, jog 12 tiriamujų (40 proc.) statinè pusiausvyra bloga, 11 patenkinama, 4 vidutinè ir 3 pasiekè puikius statinès pusiausvyros rezultatus. Apibendrinus, tiriamujų statinè pusiausvyra buvo vidutinè ir žemesnè už vidutinę normą.

Atlikus liemens ir kojų raumenų funkcinio pajėgumo bei pusiausvyros rezultatų koreliacinę analizę (1 lentelè), nustatyta statistiškai reikšminga $(\mathrm{p}<0,05)$ vidutinè koreliacija tarp izometrinès liemens raumenų jègos (liemens lenkimas, tiesimas, lenkimas ị kairę, lenkimas ị dešinę) ir izometrinès apatinių galūnių raumenų jègos (šlaunies tiesimo, atitraukimo ir pritraukimo). Izometrinè liemenį tiesiančių raumenų jëga reikšmingai koreliavo su dinamine pusiausvyra, o izometrinė nugaros bei šoninių liemens raumenų jèga statistiškai reikšmingai koreliavo su apatinių galūnių ištverme.

Izometrinès kojų raumenų jègos ir pusiausvyros duomenų analizè ( 2 lentelè) parodè statistiškai reikšmingą $(\mathrm{p}<0,05)$ vidutinę koreliaciją tarp kojų raumenų jègos ir dinaminès pusiausvyros, tačiau koreliacija tarp kojų raumenų ir statinès pusiausvyros buvo silpna ir statistiškai nereikšminga. Statistiškai reikšmingai koreliavo apatinių galūnių ištvermė ir statinè pusiausvyra $(\mathrm{p}<0,05)$.

J. Ambegaonkar su bendraautoriais, ištyręs kolegijos atletų liemens raumenų ištvermę ir pusiausvyrą, taip pat nerado koreliacijos tarp jų [2]. A. Barati su kolegomis taikè panašius testus kaip ir mūsų tyrime, tačiau gavo visiškai priešingus rezultatus, nei J. Ambegaonkar. Mokslininkų tyrime, liemens raumenų ištvermè statistiškai reikšmingai koreliuoja su statine pusiausvyra [12].

M. Kim ir S. Kim savo tyrime ieškodami sąsajų tarp apatinių galūnių raumenų ir pusiausvyros, rado koreliaciją tarp statinès pusiausvyros ir šlauni lenkiančių raumenų [13]. T. Muehlbauer su bendraautoriais sistemineje straipsnių apžvalgoje išanalizavę 39 straipsnius, susijusius su apatinių galūnių raumenų jëga ir pusiausvyra (9 straipsniai atitiko mūsų tiriamųjų amžiaus grupę), rado labai silpną koreliaciją. Nors dinaminès pusiausvyros ir kojų raumenų jëgos koreliacijos koeficientas buvo didesnis, ryšys buvo silpnas. Jų teigimu, kojų raumenų jẻga ir pusiausvyra yra nesusiję komponentai [14].

\section{Išvados}

Ištyrus ketvirto kurso kineziterapijos studentų funkcini liemens pajègumą, nustatyta, kad tiriamujjų izometrinès pilvo ir nugaros raumenų jègos santykis ir šoninių liemens raumenų jègos santykis yra patenkinamas. Vertinant kojų raumenų funkcinį pajègumą, nustatyta, jog tiriamujų izometrinės šlaunį tiesiančių, atitraukiančių ir pritraukiančių raumenų kairès ir dešinès kojos jègos santykis yra patenki- 
namas. Statinė pusiausvyra patenkinama.

Analizuojant liemens, kojų raumenų pajègumo ir pusiausvyros tarpusavio ryšius, nustatyta, kad kuo didesnè izometrinè liemens raumenų jèga, tuo didesnè kojų raumenų jèga. Didesnè nugaros raumenų jèga lemia geresnę dinaminę pusiausvyrą. Kuo didesnè izometrinè kojų raumenų jèga, tuo geresnè dinaminė pusiausvyra ir geresnè kojų raumenų ištvermè, lemianti geresnę statinę pusiausvyrą.

\section{Literatūra}

1. Radžiūnas K., Radžiūnienè M., Čiuželis T., Vainoras A., Poderys J. Liemens raumenų fizinio pajegumo ir funkciniu judesių sąsajos.. Sporto mokslas,2016;3(85):50-58.

https://doi.org/10.15823/sm.2016.32

2. Ambegaonkar JP, Mettinger LM, Caswell SV, Burtt A, Cortes N. Relationships between core endurance, hip strength, and balance in collegiate female athletes. International Journal of Sports Physical Therapy 2014;9 (5), 904-916.

3. Boonstra T, Schouten A, van der Kooij H. Identification of the contribution of the ankle and hip joints to multi-segmental balance control. Journal of NeuroEngineering and Rehabilitation 2013;10(1):23.

https://doi.org/10.1186/1743-0003-10-23

4. Aggarwal A, Zutshi K, Munjal J, Kumar S, Sharma V. Comparing stabilization training with balance training in recreationally active individuals. International Journal of Therapy and Rehabilitation 2010;17(5):244-253.

https://doi.org/10.12968/ijtr.2010.17.5.47843

5. McLay R, O'Hoski S, Beauchamp M. Role of muscle strength in balance assessment and treatment in chronic obstructive pulmonary disease. Cardiopulmonary Physical Therapy Journal 2019;30(1):35-43.

https://doi.org/10.1097/CPT.0000000000000093

6. Crawford R, Volken T, Schaffert R, Bucher T. Higher low back and neck pain in final year Swiss health professions' students: worrying susceptibilities identified in a multi-centre comparison to the national population. BMC Public Health 2018;18(1). https://doi.org/10.1186/s12889-018-6105-2

7. MockevičienėD, Bakanovienė T, SavenkovienėA, Vaitkevičius JV, Miliūniené L. Assessment of the isometric muscle force balance in persons having back pains. Health Sciences 2012;22(5 (84):9-12.

8. Muliarčikas A. ir kt. Mokomoji knyga: Lietuvos gyventojų fizinio pajègumo testavimo ir fizinès būklès nustatymo metodika. Sveikos gyvensenos, fiziškai aktyvaus gyvenimo būdo ir jo praktinio realizavimo metodinès rekomendacijos. Kaunas: Lietuvos sporto informacijos centras, 2007.

9. Plisky PJ, Gorman PP, Butler RJ, Kiesel KB, Underwood FB, Bryant EB. The reliability of an instrumented device for measuring components of the star excursion balance test. North American Journal of Sports Physical Therapy 2009;4 (2), 92-99.

10.Johnson BL, Nelson JK. Practical measurements for evaluation in physical education. 4th Edit. Minneapolis: Burgess, 1986.
11. Mockevičienė D., Bakanovienė T., Savenkovienė A., Vaitkevičius J.V., Miliūnienè L. Assessment of the isometric muscle force balance in persons having back pains. Health Sciences 2012;22(5 (84):9-12.

https://doi.org/10.5200/sm-hs.2012.090

12. Barati A, Safarcherati A, Aghayari A, Azizi F, Abbasi H. Evaluation of relationship between trunk muscle endurance and static balance in male students. Asian J Sports Med2013;4(4):289-294.

https://doi.org/10.5812/asjsm.34250

13. Kim M, Kim S. Analysis of the correlation between the differences in muscle strengths between the bilateral lower extremities and postural stability in healthy adults. J Phys Ther Sci 2015;27(10):3103-3104.

https://doi.org/10.1589/jpts.27.3103

14. Muehlbauer T, Gollhofer A, Granacher U. Associations between measures of balance and lower-extremity muscle strength/power in healthy individuals across the lifespan: a systematic review and metaanalysis. Sports Medicine 2015;45(12):1671-1692. https://doi.org/10.1007/s40279-015-0390-z

\section{RELATIOSHIP BETWEEN CORE AND LEGS MUSCLES FUNCTIONAL CAPACITY AND BALANCE AMONG PHYSIOTHERAPY STUDENTS I.E. Jamontaitė, G. Molevičiūtė, I. Muntianaitė,} L. Aučynienè, A. Cirtautas, R. Žilinskienė

Keywords: core muscle strength, legs muscle strength, legs muscle endurance, functional capacity, balance, physiotherapy students.

Summary

The aim of research work. Identify relationship between core and legs muscles functional capacity and balance among physiotherapy students. Materials and methods. 30 physiotherapy students participated in the study and the average age of research subjects was $22,4 \pm 1,2$ years. The core and legs isometric muscle strength of the subjects has been measured using diagnostic equipment "Back-Check" by Dr. Wolff, legs muscles endurance using Squat Test, static balance using Stork's Static Balance Test, dynamic balance using Y Balance Test. Data analysis has been conducted using "Microsoft Office Excel 2010" ir "R Commander" software. Results and conclusions. Core and legs muscles functional capacity among physiotherapy students was satisfactory. Lower extremities endurance was sufficient. The static balance among physiotherapy students was evaluated as sufficient and dynamic balance was good. Analysis of the relationship between core, legs muscles capacity and balance shows that the better isometric core muscles strength the better legs muscle strength. The better isometric back muscles strength to determine the better dynamic balance. The better isometric legs strength the better dynamic balance and the better lower extremities endurance the better static balance.

Correspondence to: ieva.jamontaite@mf.vu.lt

Gauta 2020-01-23 